\title{
GEOLOGIC FRAMEWORK OF KARST AQUIFER SYSTEMS IN ALABAMA
}

\section{Gheorghe M. Ponta}

Geological Survey of Alabama 420 Hackberry Lane, Tuscaloosa, Alabama 35401, gponta@gsa.state.al.us

\begin{abstract}
Extreme droughts in recent years have highlighted the need to enhance management and protection actions for the water resources of Alabama. The Groundwater Assessment Program (GAP) of the Geological Survey of Alabama investigates the availability and quality of the states' groundwater resources working in cooperation with other state and federal agencies, local governments and water systems, industry, educational institutions, and citizens.
\end{abstract}

Alabama is located in the humid region of the United States, with numerous karst features, such as caves, sinkholes (dolines), and springs occurring in carbonate (limestone and dolomite) rocks, which underlie about $25 \%$ of the state. In the Interior Low Plateaus (Western and central part), Appalachian Plateaus, and Valley and Ridge Physiographic Provinces, which are in the northern half of the state, carbonate rocks underlie many areas and groundwater is contained mainly in karstified aquifers with high secondary porosities. The southern half of the state is situated in the Coastal Plain physiographic province, where around $7.5 \%$ of the aquifers are located in carbonates rocks.

All wells installed in carbonate rocks and karst springs obtain water from solution cavities in these strata or the regolith above them. These solution cavities are not uniformly distributed, making prediction of their occurrence extremely difficult. To better understand the geologic framework of karst aquifer systems in Alabama, a series of hydrogeological cross-sections were constructed depicting stratigraphy and aquifers in the area. The selection of cross-section lines and wells were based on their geographic location, with preference given to wells having a greater total depth and with supporting geophysical and sampling logs. These crosssections were used to identify geologic structure, aquifers (depth and elevation) and their production intervals, and determine where deeper aquifers might be located.

The economic future and quality of life for Alabamians, as well as sustainable ecosystem functions and services, are dependent upon the availability and protection of the state's water resources. Therefore, future water source development will require significant scientific research, substantial logistical planning, and infrastructure development to find and manage water sources.

\section{Introduction}

Alabama's climate is humid subtropical with warm, summers and typically mild winters. Precipitation generally occurs year round, except during drought periods, varying from 1,270-1,372 $\mathrm{mm}$ in the Tennessee Valley to 1,524-1,651 mm along the coast. (Stringfield et al., 1974; Evans, 1998).

Alabama, with an area of $135,765 \mathrm{~km}^{2}$, is located in the southeastern United States and has a karstifiable area of about $34,051 \mathrm{~km}^{2}$ (approximately $25 \%$ ). ${ }^{1}$

\section{Karst}

The karstifiable rocks (limestones, dolomite) of the northern half of Alabama (approximately 17.5\%) are mostly Paleozoic deposits, while rocks in the southern part of Alabama belong mainly to Mesozoic or Neogene deposits representing 7.5\% (Figure 1).

The Alabama karst landscape was generated mainly in the Quaternary. The most karstified deposits belong to the Paleozoic sedimentary cycle. The largest exposed carbonates region in the state, and the most karstified area is in Appalachian Plateaus Province. Based on the geomorphological and structural aspects, there are two types of karst landscapes specific to Alabama:

- Plateau type karst characterized by large limestones, dolomite or chert plateaus with surface karstic features like dolines (sinkholes), closed depressions, dry valleys and streams with elevation ranging between $100 \mathrm{~m}$ to $300 \mathrm{~m}$. The

'All areas in $\mathrm{km}^{2}$ or percent were estimated based on the Szabo et al. (2006) Digital Version of the Geologic map of Alabama. 
most important plateaus are in the Interior Low Plateaus and Appalachian Plateaus Provinces.

- Bar/Ridge type karst features are ridges derived from carbonate deposits alternate with non-soluble rocks, which dip at over $45^{\circ}$. Very prominent ridges appear because of the differential erosion processes. The strike of these is controlled by northeast southwest longitudinal faults with regional extension, and is cut by transverse faults, on which the karst aquifer is opened and emerges to the surface through springs. The most representative ridges are in the Valley and Ridge Province.

The main karst features present in Alabama and discussed briefly in this paper are: sinkholes, caves and springs. In Alabama, the most common causes of land subsidence are the development of sinkholes in areas underlain by soluble carbonate rocks that are susceptible to dissolution and the formation of caves and sinkholes. More than 6000 sinkholes are recorded (based on the 7.5' USGS topographic maps $/>10 \mathrm{~m}$ across or larger), developed mainly in the northern half of the state, with the highest concentration in the Appalachian Plateaus Province (Ebersole and Tavis, 2010; Ebersole and Hill, 2016).

Over 4,386 caves ${ }^{2}$ are known in Alabama, developed in limestones and dolomite. Most of the caves are in the Bangor Limestones (1369), about 211 caves in the Monteagle limestones, and 141 caves in the Tuscumbia limestones. The largest numbers of caves (3422) are located in Appalachian Plateaus Province, the longest one is $25,153 \mathrm{~m}$ and the deepest one is $-184 \mathrm{~m}$. In the Valley and Ridge Province are recorded 513 caves, the longest one is $5.4 \mathrm{~km}$ and the deepest is $-95 \mathrm{~m}$. In the Interior Low Plateaus province are known 216 caves, the longest is $3.34 \mathrm{~km}$ and the deepest is $-60 \mathrm{~m}$. In the Coastal Plain Province there are 113 known caves, with a maximum length of $417 \mathrm{~m}$ and $-15 \mathrm{~m}$ vertical range. Overall, the longest cave is over $25 \mathrm{~km}$ long and the deepest one is $-184 \mathrm{~m}$.

The Alabama karst landscape was generated mainly in the Quaternary. The most karstified deposits belong to the Paleozoic sedimentary cycle. The largest exposed carbonates region in the state, and the most karstified area, is in Appalachian Plateaus Province.

${ }^{2}$ All cave numbers are from Alabama Cave Survey database, as April 9, 2017.
About $40 \%$ of public water supply by volume is derived from groundwater sources, and $70 \%$ of the geographic area of Alabama is supplied by groundwater sources. Karst springs are numerous in the state, several being used as public or domestic water supply (Hutson et al., 2009). On Figure 1 are shown 109 springs, which are measured (discharge) and sampled periodically. Because of the high number of sinkholes and caves in the state, they are not shown on our figures. The distribution and density of the sinkholes and caves is comparable with those of the springs.

\section{Cross Sections}

In order to understand the geologic framework of karst aquifer systems in Alabama, a series of geological cross sections were constructed depicting the stratigraphy of the study area. The selection of wells included along a particular cross-section line was based on the availability of sample logs and associated electric logs.

The Geological Survey of Alabama (GSA) has a large water well record file (more than 125,000), and geochemical data dating to the early 1900s. Because geophysical well logs were completed only in a small number of the water wells and test holes drilled in the area, well-log data from oil and gas wells were used to generate the cross sections. The State of Alabama Oil and Gas Board (OGB) has a large oil and gas well database (more than 17,000 wells). These water well data will be critical to Alabama's water future and are managed using the GSA RBDMS-ENV (Risk Based Data Management System-Environmental) database (GSA, 2017).

Use of these cross sections allows rapid determination of which aquifer is screened. These cross sections are also important in planning for the exploitation of an aquifer. The cross sections will be critical in further exploitation of an existing aquifer or future exploration for new resources as well as in aquifer contamination risk assessments (GSA, 2017).

Due to space restriction, only one cross section (A-A') will be presented in this paper (Figure 2). The others will be available online in the near future, at www.gsa.state.al.us.

\section{Geology and Karst Features Distribution in Physiographic Provinces}

Five major physiographic provinces are recognized in Alabama: the Interior Low Plateaus, Appalachian 


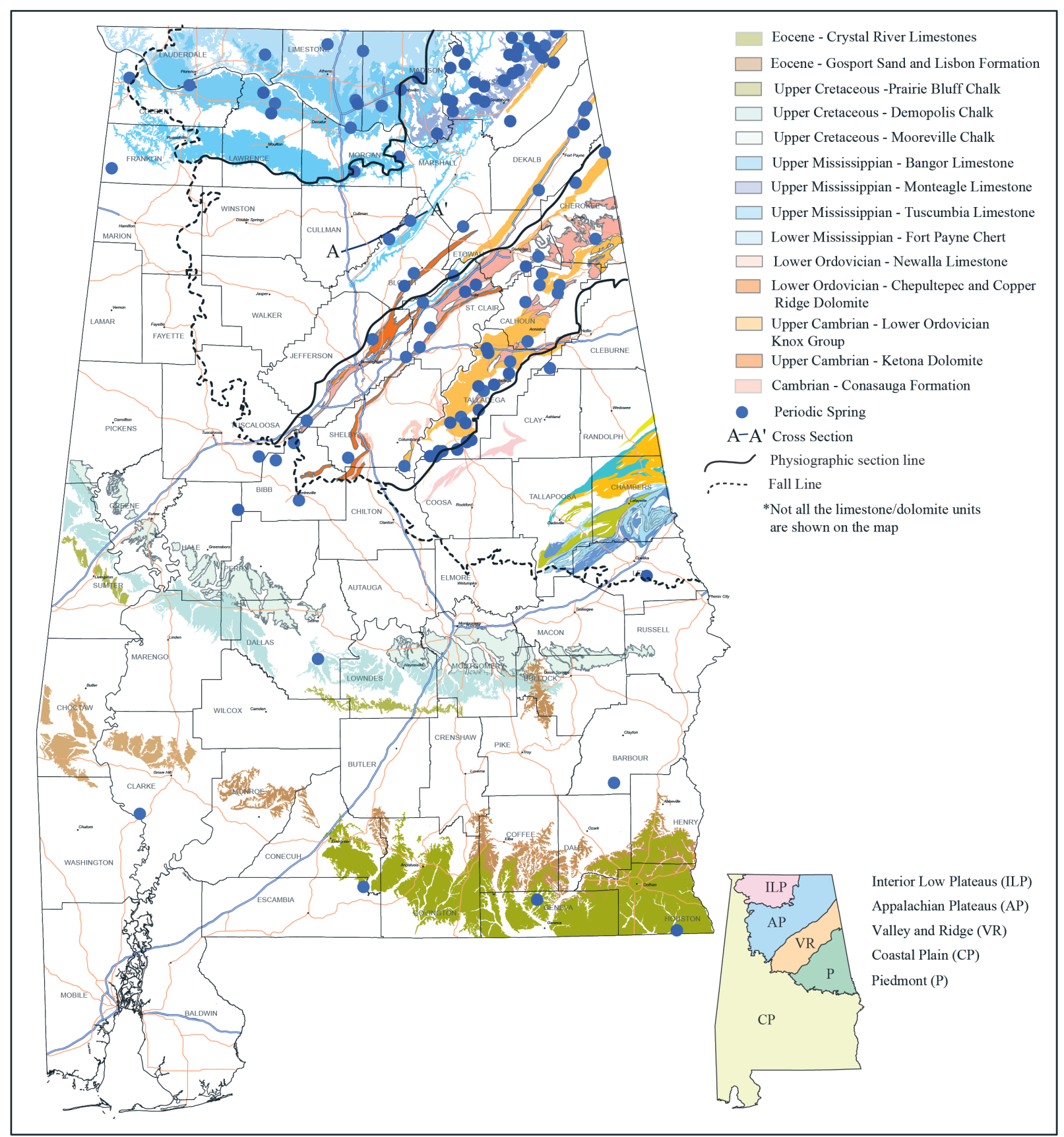

Figure 1. Karst areas of Alabama. Geology modified after Osborne et al. (1989). Not all limestones/dolomites units are shown on the map.

Plateaus, Valley and Ridge, Piedmont, and Coastal Plain (Harper, 1920, 1942, 1943, Johnson, 1930, Fenneman, 1938, Pierce, 1966, Sapp and Emplaincourt, 1975, and Mettee et al., 1996).

\section{Interior Low Plateaus Province - Mississippian Age Limestones/Chert/Dolomite Deposits}

The Interior Low Plateaus Province is located in the northwest part of the state and is traversed by the
Tennessee River from east to west. The Tuscumbia Limestone and Fort Payne Chert are predominantly present along the Tennessee River, outcropping in the area at elevations around $120 \mathrm{~m}$ to $170 \mathrm{~m}$. South of Tennessee River, the Tuscumbia Limestone is overlain by the Bangor Limestone which outcrops as an east-west strip. In the eastern side of the section the Monteagle Limestone is present in small exposures. 


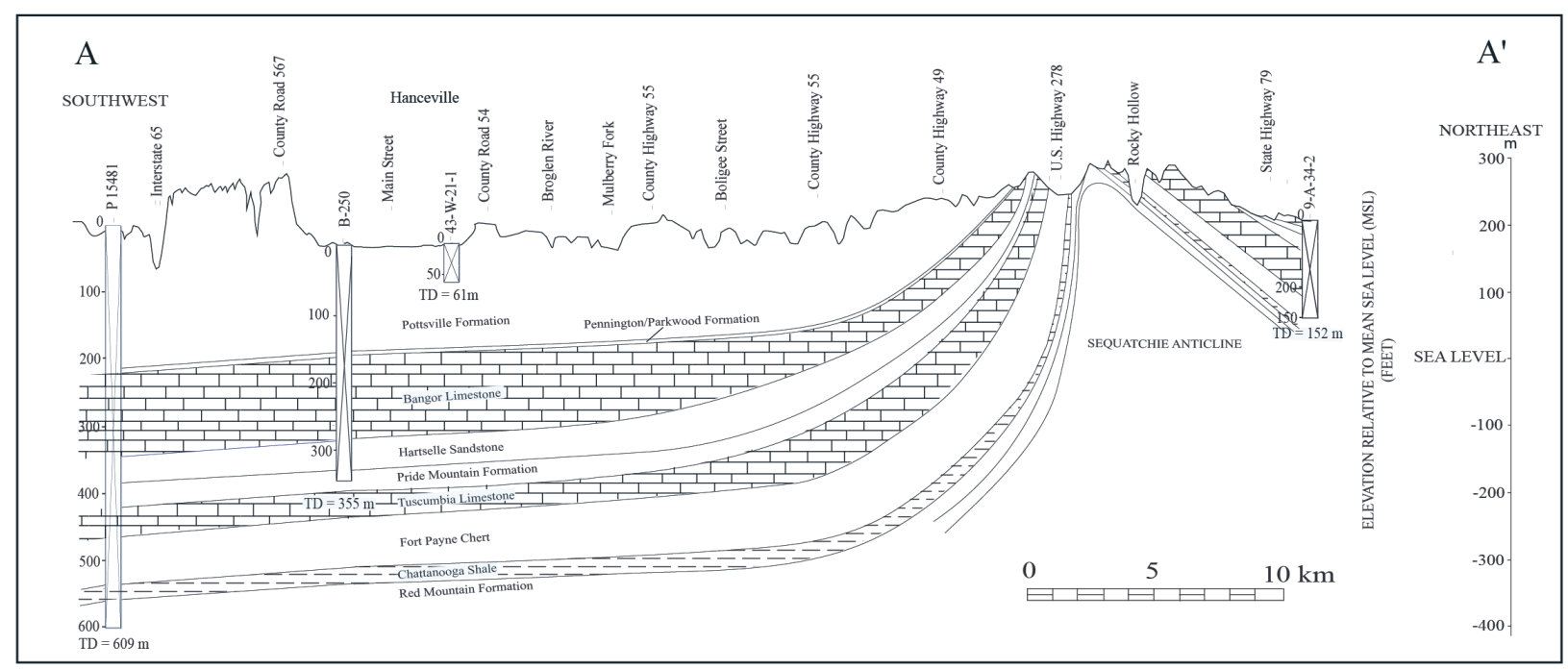

Figure 2. Cross section A-A'. Location of cross section line shown on Figure 1.

The Tuscumbia Limestone is a light-gray bioclastic or micritic, partly oolitic limestone in beds that generally are more than $30 \mathrm{~cm}$ thick. Thickness ranges from 0 to $75 \mathrm{~m}$ (Thomas, 1972).

The Fort Payne Chert consists of limestone with abundant irregular chert nodules and beds. The Tuscumbia Limestone and Fort Payne Chert overlie the Chattanooga Shale, which is an aquiclude that can reach a thickness of up to $25 \mathrm{~m}$ (Butts, 1926).

The Monteagle Limestone consists of limestone, dolomite, and shale, and the Bangor Limestone consists primarily of medium to light gray, bioclastic, and oolitic limestone and overlay the Tuscumbia Limestones. Thickness range between 60 and 90 meters.

The Bangor Limestone is an unconfined karst aquifer in the Interior Low Plateaus Province. Groundwater movement is through secondary porosity conduits and solution enhanced fractures, which discharges to springs. The thickness of the Bangor Limestone in the Interior Low Plateau Province can range up to $150 \mathrm{~m}$. The Bangor aquifer is unconfined throughout the entire Interior Low Plateaus Province area. Plateau-type karst dominates the region and numerous sinkholes are identified in the area, some large in diameter and a few meters deep.

About 216 caves are known in the area, the longest one being Key Cave (Lauderdale County) with over $3 \mathrm{~km}$ of passages disposed in a labyrinthic maze. The deepest cave is Craigs Mill Bluepond -60 m located in Cherokee County. Numerous springs are present, the largest one being Tuscumbia Spring (Colbert County) with a discharge of $1,700 \mathrm{~L} / \mathrm{s}$.

Major aquifers in the Interior Low Plateaus Province are the Tuscumbia Limestone and the Fort Payne Chert. However, there are several minor aquifers including the Bangor Limestone, and Monteagle Limestone (GSA, 2017).

\section{Appalachian Plateaus Province - Cambrian through Mississippian Age Limestones/Dolomites/Chert Deposits}

The Appalachian Plateaus Province, located in north central, northeastern, and west Alabama is an undulating surface frequently dissected by valleys. Elevations range from around $200 \mathrm{~m}$ at Tuscaloosa to near $500 \mathrm{~m}$ in the Jackson Mountains northeast of Huntsville and Lookout Mountain near Mentone.

The limestones and dolomites outcropping in the Appalachian Plateaus in Alabama include the Conasauga Formation, Brierfield Dolomite, Ketone Dolomite, and Knox Group (Copper Ridge Dolomite, Chapultepec Dolomite, Longview Limestone, and Newalla Limestone), Chickamauga Limestone, Tuscumbia Limestone, Fort Payne Chert, Monteagle Limestone, and the Bangor Limestone. The Pottsville Formation is considered to be the major aquifer and the Conasauga Formation is the oldest unit in the Appalachian Plateaus Province.

The Tuscumbia Limestone and Fort Payne Chert overlies the Chattanooga Shale in the southern and northeastern 
sections of the Appalachian Plateaus Province. These units serves as a minor aquifer in the area and wells are primarily public and domestic supply wells.

Cross Section A-A' is located in the eastern part of the Appalachian Plateaus Province and ends in the Valley and Ridge Province, showing the relationship between the Tuscumbia Limestone and Bangor Limestone with the non-carbonaceous rocks. In the southwestern end of the cross section, the wells are screened/opened in the karst aquifers of Tuscumbia Limestone, Fort Payne chert, and Bangor Limestone. At the northeastern end of the cross section, wells are completed in the Valley and Ridge Province and karst aquifers are the primary sources of water. Spring discharge is generally less than $100 \mathrm{~L} / \mathrm{s}$ with some springs used as public water supply. About 3422 caves are known in the area, the longest one being Fern Cave (Jackson County) with over $25 \mathrm{~km}$ of passages disposed in labyrinthic maze. The deepest cave Obscure Magnificence is $-184 \mathrm{~m}$, and is located in Jackson County.

\section{Valley and Ridge Province - Cambrian through Mississippian Age Limestones/ Chert/Dolomites Deposits}

The Alabama Valley and Ridge consists of a series of folded and faulted parallel ridges and valleys that trend northeast-southwest with elevations ranging from $175 \mathrm{~m}$ to $650 \mathrm{~m}$. Ridges are made of sandstone and chert while valleys are generally developed on limestone and shale. In this province a ridge type karst is present. Sinkholes are sporadic, small in diameter and a few meters deep.

The Valley and Ridge karst aquifer system consists of several Paleozoic strata of Cambrian to Devonian (Mississippian) age including the Shady Dolomite (limestone, dolomite, chert, and silty clay), Conasauga Formation (limestone, dolomite, and shale of varying proportions), Brierfield Dolomite (dolomite with locally abundant chert), Ketona Dolomite (mostly chert free, remarkably pure dolomite), Bibb Dolomite (siliceous dolomite characterized by locally abundant chert), Knox Group (dolomite, siliceous dolomite, dolomitic limestone, cherty limestone, and chert-free, relatively pure micritic limestone), and the Little Oak Limestone- Lenoir Limestone (limestone, chert, bentonite) (GSA, 2017).

The Bangor and Monteagle Limestone formations serve as a major water source within the Alabama Valley and
Ridge predominantly used for public supply, although several domestic and agricultural wells are also known.

About 513 caves are known in the area, the longest one being $5.4 \mathrm{~km}$ long (Anderson Cave, Shelby County), and the deepest one being $-94 \mathrm{~m}$ (Bat in the Pocket Cave, Etowah County). Numerous springs are present, and some are in use by municipalities (e.g., Warren Spring, Blount County).

\section{Coastal Plain Province}

The Coastal Plain Province in Alabama is characterized by gently rolling hills, sharp ridges, prairies, and broad alluvial flood plains. Calcareous rocks underlying the Coastal Plain are of sedimentary origin and consist of porous limestone, chalk, and marl. These strata dip underground to the southwest at approximately 6 to $7.5 \mathrm{~m}$ per $\mathrm{km}$ and strike generally in east-west belts.

The Selma Group is comprised of the Mooresville Chalk, Demopolis Chalk, and the Prairie Bluff Chalk in western Alabama, and the Blufftown Formation in eastern Alabama (Monroe, 1941).

The chalk is mainly calcareous marl with dark gray color, hosting very few to no karst surface and underground features even though they outcrop extensively in the southern half of the state. These units are aquicludes that reach a thickness of up to several tens of meters.

The Paleogene calcareous deposits of the Coastal Plain Province are represented by the Lisbon and Crystal River Formations. Toulmin and LaMoreaux (1963) reported that the Lisbon Formation outcrops in southeast Alabama consists primarily of sand but also contains significant amounts of limestone and sandy limestone. The Lisbon aquifer is a major public, domestic, agricultural, and industrial water source for central and southeastern Alabama.

The Crystal River Formation includes all calcareous deposits of late Eocene age lying stratigraphically above the Moody's Branch and below limestone beds of Oligocene age (Smith, 2001). The Crystal River Formation is characterized by white to cream mediumtextured to coquinoid limestone that is soft and chalky to compact and brittle (Puri, 1953, 1957).

The Chickasawhay Formation (Oligocene series), which overlies the Vicksburg Group, consists of bluish-gray, 
glauconitic, soft, sandy calcareous clay, and layers of hard white limestone (Copeland, 1966).

The karst developed in the Coastal Plain Province is plateau type karst. Sinkholes were identified in the area, some large in diameter and only a few meters deep.

About 113 caves are known in the area; the longest one being only $417 \mathrm{~m}$ long (Lion's Den, Clarke County) and the deepest cave is $-15 \mathrm{~m}$ (Chastain Cave, Clark County). A few small to medium size springs are present in the area. The numbers of surface and underground karst features is a result of the presence of porous limestones, where karst features are poorly preserved.

\section{Piedmont Province}

The Piedmont province is a section of the "older Appalachians" as described by Fenneman (1938). This undulating plain is the result of long-term degradation of the surface rocks while the underlying rocks are severely deformed and angled to the surface. The Piedmont province in Alabama is a wedge shaped feature bounded on the south by coastal plain sediments and to the northwest by the Alabama Valley and Ridge. Piedmont geology is complex consisting of high- and low-grade metamorphic and igneous rocks including quartzite, phyllite, slate, schist, amphibolite, and gneiss (GSA, 2017). There are some sinkholes in the Sylacauga Marble.

\section{Acknowledgements}

The author would like to acknowledge the Geological Survey of Alabama Groundwater Assessment Program team that made this work possible. In addition I would like to acknowledge the Alabama Cave Survey who provided access to caves database.

\section{References}

Butts C. 1926. The Paleozoic rocks. In Geology of Alabama: Alabama Geological Survey Special report 14 , p. 162-167.

Copeland CW, ed. 1966. Facies changes in the Alabama Tertiary: A Guidebook for the Fourth Annual Field trip of the Alabama Geological Society, $103 \mathrm{p}$.

Ebersole S, Tavis A. 2010. Alabama sinkhole mapping project, GSA Open-File Report 1005, 2 pages, 1 map, and GIS data.

Ebersole S, Hill M. 2016. Karst supplemental data to the National hydrography dataset for northern Alabama watersheds, GSA Open-File Report 1609, 13 pages and GIS data.

Evans CM. 1998. The Complete Guide to Alabama Weather. Birmingham, AL: Seacoast Publishing, $112 \mathrm{p}$.
Fenneman NM. 1938. Physiography of eastern United States: New York, McGraw-Hill, 714 p.

Geological Survey of Alabama (GSA). 2017. Assessment of groundwater resources in Alabama, 2010-16: Alabama Geological Survey Open-File Report 1606, 426 p., 105 plates.

Harper RM. 1920. Resources of southern Alabama: Alabama Geological Survey Special Report 11, $152 \mathrm{p}$.

Harper RM. 1942. Natural resources of the Tennessee Valley region in Alabama: Alabama Geological Survey Special Report 17, 93 p.

Harper RM. 1943. Forests of Alabama: Alabama Geological Survey Monograph 10, 230 p.

Hutson SS, Littlepage TM, Harper MJ, Tinney JO. 2009. Estimated use of water in Alabama in 2005: U.S. Geological Survey Scientific Investigations Report 2009-5163, 210 p.

Johnston WD, Jr. 1930. Physical divisions of northern Alabama: Alabama Geological Survey Bulletin $38,48 \mathrm{p}$.

Mettee MF, O’Neil PE, Pierson JM. 1996. Fishes of Alabama and the Mobile Basin: Alabama Geological Survey Monograph No. 15, 820 p.

Monroe WH. 1941. Notes on deposits of Selma and Ripley age in Alabama: Alabama Geological Survey Bulletin 48, p. 73-88.

Osborne WE, Szabo MW, Copeland CW, Jr., Neathery TL. 1989. Geologic map of Alabama: Alabama Geological Survey Special Map 221, scale $1: 500,000$.

Puri HS. 1953. Zonation of the Ocala Group in peninsular Florida (abs.): Journal of Sedimentary Petrology, v. 23, no.2, p. 130.

Puri HS. 1957. Stratigraphy and zonation of the Ocala Group: Florida Geological Survey Bulletin 38, p. 31-38.

Sapp CD, Emplaincourt J. 1975. Physiographic regions of Alabama: Alabama Geological Survey Special Map 168.

Smith CC. 2001. Implementation assessment for water resources availability, protection, and utilization for the Choctawhatchee, Pea, and Yellow Rivers watersheds: Geological Survey of Alabama Openfile Report, 148 p. 